University of Nebraska - Lincoln

DigitalCommons@University of Nebraska - Lincoln

USDA National Wildlife Research Center - Staff Publications
U.S. Department of Agriculture: Animal and Plant Health Inspection Service

2000

\title{
Hazing and Movements of Canada Geese near Elmendorf Air Force Base in Anchorage, Alaska
}

\author{
Darryl L. York \\ US Department of Agriculture, Animal and Plant Health Inspection Services, National Wildlife Research \\ Center \\ John L. Cummings \\ US Department of Agriculture, Animal and Plant Health Inspection Services, National Wildlife Research \\ Center \\ Richard M. Engeman \\ USDA-APHIS-Wildlife Services, s_r100@yahoo.com \\ Kate L. Wedemeyer \\ U. S. Department of Defense
}

Follow this and additional works at: https://digitalcommons.unl.edu/icwdm_usdanwrc

Part of the Environmental Sciences Commons

York, Darryl L.; Cummings, John L.; Engeman, Richard M.; and Wedemeyer, Kate L., "Hazing and Movements of Canada Geese near Elmendorf Air Force Base in Anchorage, Alaska" (2000). USDA National Wildlife Research Center - Staff Publications. 808.

https://digitalcommons.unl.edu/icwdm_usdanwrc/808

This Article is brought to you for free and open access by the U.S. Department of Agriculture: Animal and Plant Health Inspection Service at DigitalCommons@University of Nebraska - Lincoln. It has been accepted for inclusion in USDA National Wildlife Research Center - Staff Publications by an authorized administrator of DigitalCommons@University of Nebraska - Lincoln. 


\title{
Hazing and movements of Canada geese near Elmendorf Air Force Base in Anchorage, Alaska
}

\author{
Darryl L. York ${ }^{\mathrm{a}, *}$, John L. Cummings ${ }^{\mathrm{a}}$, Richard M. Engeman ${ }^{\mathrm{a}}$, Kate L. Wedemeyer ${ }^{\mathrm{b}}$ \\ ${ }^{a}$ US Department of Agriculture, Animal and Plant Health Inspection Services, National Wildlife Research Center, 4101 LaPorte Avenue, Fort \\ Collins, CO 80521, USA \\ ${ }^{\mathrm{b}}$ US Department of Defense, 3CES/CEV, 22040 Maple Street, Elmendorf Air Force Base, Anchorage, AK 99506-3240, USA
}

\begin{abstract}
Bird strikes to aircraft are a serious economic and safety problem in the United States, annually causing millions of dollars in damage to civilian and military aircraft and the occasional loss of human life. We observed movements of 1236 neckbanded lesser Canada geese (Branta canadensis parvipes) to determine efficacy of hazing as a means to reduce goose presence at Elmendorf Air Force Base (EAFB), Anchorage, Alaska from August to October 1997. Emphasis was on movements of geese onto EAFB with additional data collected at the other two major airports in the area, Anchorage International Airport (AIA) and Merrill Field Airport (MFA). Daily observations indicated the presence of 208 individual neckbanded geese on EAFB, and $20 \%$ returned more than once after being hazed from EAFB. We identified three staging areas, geese utilized prior to entering EAFB, and three post-hazing dispersal sites. Collared geese began moving onto EAFB $30-40$ days post-molt with the largest proportions moving onto EAFB 70-90 days post-molt. We observed 75 neckbanded geese on AIA from seven molting sites, and $23 \%$ returned more than once after being hazed from AIA. We observed 141 neckbanded geese on MFA from 14 molting sites, and $21 \%$ returned more than once after being hazed from MFA. Our data indicated that as long as local goose populations increase, large numbers of Anchorage area geese are likely to enter one of the airports creating a variety of management problems. Hazed geese returning to airports multiple times present a special hazard to aircraft safety because they appear to have become habituated to non-lethal scare tactics. We recommend an integrated management approach to limit the Anchorage area goose population utilizing various control techniques which are acceptable to Anchorage residents while continuing the hazing program at area airports. (C) 2000 Elsevier Science Ltd. All rights reserved.
\end{abstract}

\section{Introduction}

Bird strikes to aircraft are a serious safety and economic problem in the United States, annually causing damage worth millions of dollars to civilian and military aircrafts and occasionally, loss of human life (Cleary et al., 1998). Military aircraft are especially susceptible to bird strikes because many exercises involve high speeds at low altitudes, where birds are commonly present. Losses of military aircraft have been numerous and costly (Blokpoel, 1976). The Uni-

\footnotetext{
* Corresponding author. Tel.: + 1-970-266-6121; fax: + 1-970-2666138.

E-mail address: daryl.1.york@usda.gov (D.L. York).
}

ted States Air Force reported 13,427 bird/wildlife strikes to aircraft world-wide from 1989 to 1993 (Arrington, 1994).

On 22 September 1995 at Elmendorf Air Force Base (EAFB) in Anchorage, Alaska, an E-3 Sentry Airborne Warning and Control System (AWACS) aircraft was taking off when several Canada geese flew up in front of the aircraft and were ingested into the two left engines, destroying one and causing the other to lose power. The crew was unable to maintain control of the disabled aircraft and crashed less than a mile from the runway killing all 24 people aboard (Bird, 1996).

Canada geese may soon become the most common bird species involved in aircraft bird strikes as a result of population increase and propensity to become per- 
manent residents in urban environments (Forbes, 1996; Cleary et al., 1997). In Anchorage, Alaska, lesser number of Canada geese (Branta canadensis parvipes) nesting and residing over summer have increased more than 10-fold during the past two decades (USFWS, 1998). This trend will continue unless control efforts are implemented to slow the population growth rate of Anchorage geese.

There are lesser Canada geese which nest in Cook Inlet and throughout river drainages from western and interior Alaska to the Yukon Territory, and they migrate along the Gulf of Alaska coast south, or up the Tanana River through British Columbia to their wintering grounds in western Oregon (Rothe, 1994). During the spring and fall migration, urban geese attract geese migrating to and from breeding grounds elsewhere in Cook Inlet and western Alaska, and during the last half of September and early October, tens of thousands of Canada geese pass through Anchorage, stopping briefly to feed when they see other geese already there (USFWS, 1998). However, since geese nest in the location where they have learned to fly, these migrants do not remain in Anchorage to nest, and are a concern to aircraft only during migration (USFWS, 1998).

In Anchorage, Alaska, number of Canada geese increased rapidly in the $1980 \mathrm{~s}$ and through the early 1990s (12-15\% annually), but now it has slowed down considerably to an annual increase of approximately $6 \%$. An estimated 4650 geese returned to Anchorage in spring 1998 (Crowley, 1998). The primary reasons for the increase in this urban goose population are the habitat and food conditions which have enhanced their productivity in the city, and low rates of harvest and natural mortality (USFWS, 1998).

Information on movements of urban geese will aid the identification of source populations of geese which move into areas that negatively impact aircraft safety, and these geese can subsequently be targeted for management activities that reduce the risk of bird/aircraft

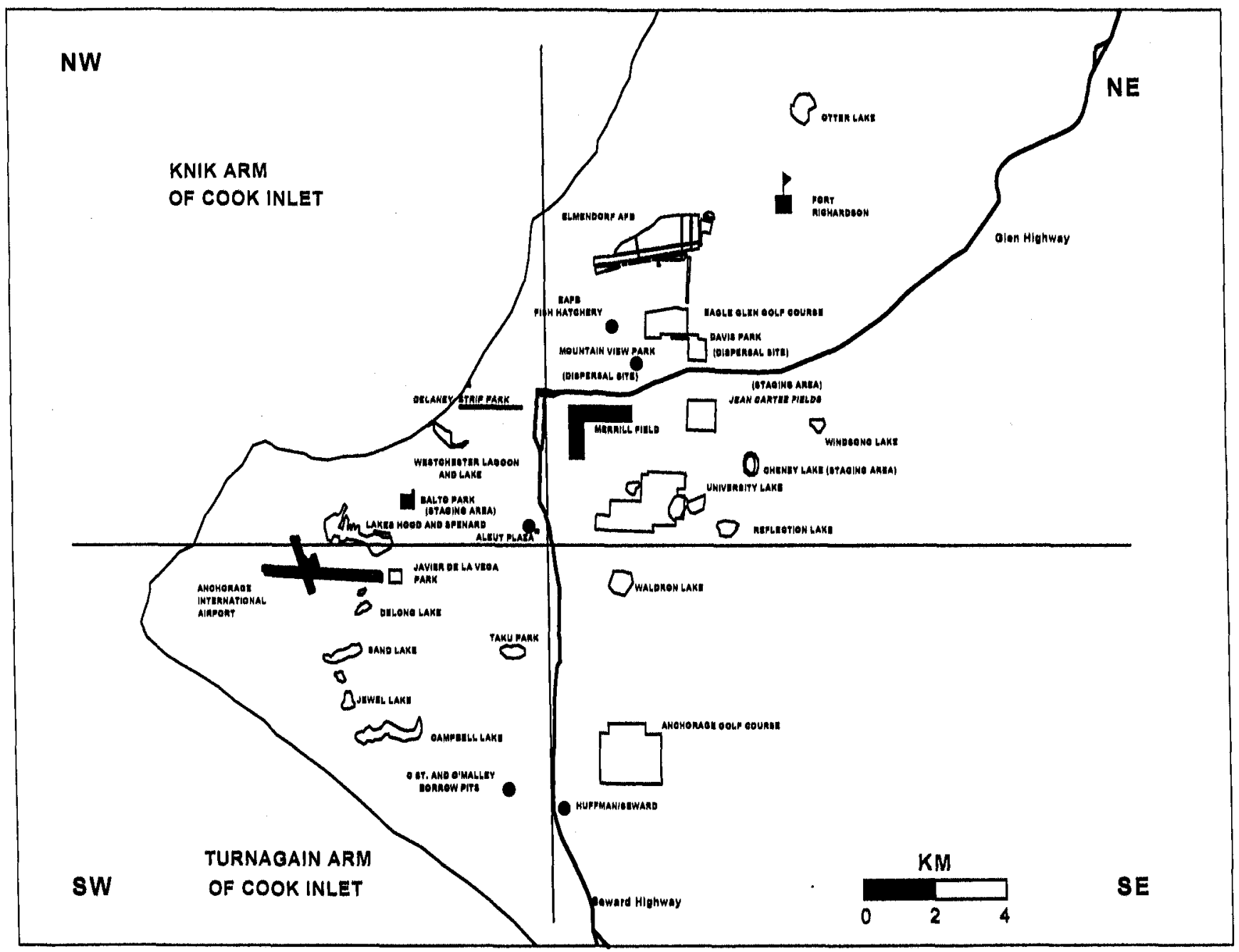

Fig. 1. Map of airports, Canada goose molting locations, staging and dispersal sites, and quadrants near Anchorage, Alaska. 
strikes. Our objectives were to ascertain local patterns of movement during post-molt dispersal; identify geese from molting sites that frequent EAFB; and evaluate the effectiveness of hazing at EAFB.

\section{Methods}

This study was conducted in Anchorage, Alaska which occupies a triangular area projecting into the Pacific Ocean with Cook Inlet's Knik Arm to the north and Turnagain Arm to the south, and the Chugach Mountain range to the northeast (Miller and Dobrovolny, 1959) (Fig. 1). Since the establishment of Anchorage in the early part of the twentieth century, local vegetation has been highly modified including the conversion of forested and bog habitats into residential and commercial developments (USFWS, 1998). Local terrain and hydrology has created a variety of freshwater wetlands, and brackish pools and marshes on coastal tidelands. Anchorage's deepwater wetlands include approximately 20 glacial kettle lakes and another 11 artificial lakes (USFWS, 1993). From 1950 to 1990 new impoundments increased surface water area from 125 to $268 \mathrm{ha}$, and lawn/grassy areas doubled as a result of new housing development (USFWS, 1993). Consequently, excellent nesting and brood-rearing goose habitat has been created by urbanization in Anchorage by the juxtaposition of mowed lawns, ballfields and numerous lakes (USFWS, 1998). Situated throughout Anchorage are the three main airports including Anchorage International Airport (AIA) which includes the floatplane base on Lakes Hood and Spenard, the municipal airport at Merrill Field (MFA), and Elmendorf Air Force Base (EAFB) (Fig. 1).

During this study, flightless geese consisting of family groups and non-breeding individuals $(n=2892)$ were driven into traps at major molting sites $(n=20)$ in Anchorage (see Fig. 1) between 8 and 22 July 1997. At least $30 \%$ of captured adult geese from each site were randomly chosen for participation in this study, regardless of whether they were previously legbanded and/or neckbanded. This study required us to recognize individual goose, so we fitted 1236 geese (979 unmarked adults, 53 juveniles and 204 previously marked adults) with a blue plastic neckband inscribed with white alpha-numeric codes. Only a small number of juveniles were marked because most were too small for neckbanding during our trapping efforts, thus the juveniles were not selected randomly. In the hope of increasing aircraft safety near airports we translocated 89 molting geese ( 79 adults and five juveniles were neckbanded) from near EAFB and 222 from near AIA (53 adults and nine juveniles were neckbanded) to an area $32 \mathrm{~km}$ north of Anchorage. Using neckband codes we were able to determine rates of return for translocated geese back into the Anchorage area.

Once geese regained flight during the first week of August, we conducted observations of neckbanded geese, Monday to Friday, to gain information on movements. With four observers, we divided Anchorage into four quadrants (NE, NW, SE, and SW; see Fig. 1) and each observer conducted observations within their respective quadrant. Initially, we attempted to provide complete daily observation coverage of the entire study area. However, the sites where geese congregate soon became apparent, and we designed survey routes around these 140 recognized sites. We reversed survey routes on alternate days to maximize opportunities to observe geese at all sites throughout the day.

EAFB military personnel dispersal teams recorded all geese observed on EAFB while engaged in bird dispersal. Bird dispersal on EAFB consisted of non-lethal as well as lethal techniques. Non-lethal methods included vehicle horns, sirens, and crackers and screamer shells. Passive methods placed near the flight line included propane cannons, and coyote effigies and scare crows wearing the same orange vest as dispersal teams. The passive deterrents were moved from one to seven times per week to give the impression of animation. Geese were hazed at least three times before resorting to killing one goose in the flock. In addition, United States Department of Agriculture, Wildlife Services (WS) personnel conducted an active bird dispersal program at AIA and MFA and also recorded goose observations. Observations continued from 13 August to 14 October 1997, when a major snowstorm forced the majority of geese to migrate to their winter range.

We used chi-square tests to determine if proportions of geese from each molting location observed on EAFB were statistically different. We determined maximum and median distances moved for neckbanded geese, and staging and dispersal sites utilized by geese following hazing. We used Product-limit survival curves (Kaplan and Meier, 1958) to describe the rates at which geese entered EAFB over time, and Wilcoxon comparisons (Kalbfleish and Prentice, 1980) to compare survival curves, where appropriate.

\section{Results}

We observed 208 individual neckbanded geese on $\mathrm{EAFB}$, and $20 \%$ returned more than once after being hazed from EAFB ( $\bar{x}=3.2, \mathrm{SE}=2.3$ visits). Percentage of geese from each molting site that were observed on EAFB is listed in Table 1. Geese neckbanded at molting sites within $9 \mathrm{~km}$ of EAFB were observed on EAFB in greater proportion $(82 \%, 171$ of 208$)$ than 
geese from outside the $9 \mathrm{~km}$ range $\left(\chi^{2}=43.28, d f=1\right.$, $P=0.001$ ) (Table 1). We observed large number of neckbanded geese from six molting sites moving onto EAFB (translocated geese grouped as a single site). The proportion of neckbanded geese moving onto EAFB from each of these six sites differed significantly $\left(\chi^{2}=26.74, d f=5, \quad P=0.001\right)$. These geese were neckbanded at 16 of the 20 molting sites $(\bar{x}=9.2$, $\mathrm{SE}=4.1 \mathrm{~km}$ from EAFB). The time between visits varied from $6.5 \mathrm{~h}$ to 42 days ( $\bar{x}=6.9, \mathrm{SE}=0.86$ days). Cheney Lake geese $(7.0 \mathrm{~km}$ from EAFB) made the most multiple visits onto EAFB ( $\bar{x}=8.0$ visits), including a male and female goose (possible mated pair) hazed from EAFB on 11 separate occasions from 5 September to 7 October. Twenty six percent (53 of 208) of neckbanded geese observed on EAFB had been translocated north of Anchorage at capture in July, and an additional $9 \%$ originated from Otter Lake, the only molting site located north of EAFB (Fig. 1; Table 1). Our chi-square tests also indicated a difference between the observed movements onto EAFB by geese neckbanded at capture sites in Anchorage $(n=$ 1056) versus translocated geese and geese neckbanded at Otter Lake $(n=180)\left(\chi^{2}=86.40, d f=1, \quad P=\right.$
0.001). A difference also existed between observed movements onto EAFB by translocated geese $(n=$ 146) versus Otter Lake geese $(n=34)\left(\chi^{2}=3.66, d f=\right.$ $1, P=0.056)$. Additionally, our surveys indicated that $96 \%$ of the neckbanded geese which had been translocated moved back into Anchorage.

The Product-limit survival estimates indicated time periods when geese moved onto EAFB in the greatest proportions. Geese began moving onto EAFB 30-40 days post-molt, and the largest proportions moved onto EAFB 70-90 days post-molt. We detected differences between Otter Lake geese and translocated geese in the movement (Product-limit survival) curves over time (Wilcoxon comparison of Kaplan-Meier survival curves; $\left.\chi^{2}=35.53,1 d f, P=0.0001\right)$. We also detected an overall difference among movement curves over time of translocated geese versus Otter Lake geese $\left(\chi^{2}=3.59,1 d f, P=0.058\right)$. We detected no differences among the five capture sites contributing the largest number of geese observed on EAFB $\left(\chi^{2}=5.28,4\right.$ $d f, P=0.26$ ).

Of geese observed on EAFB, about 80 neckbanded geese were present in Anchorage the day prior to, or the day of, the observation on EAFB.

Table 1

Neckbanded Canada geese observed on Elmendorf Air Force Base (EAFB) from Anchorage, AK molting sites, and 95\% (based on normal approximation) confidence limits (C.L.) for the percentage of neckbanded geese from each molting site observed on EAFB

\begin{tabular}{|c|c|c|c|c|c|c|c|c|c|}
\hline Quadrant & Capture site & Distance $^{\mathrm{a}}$ & $n^{\mathrm{b}}$ & $n^{\mathrm{c}}$ & $n^{\mathrm{d}}$ & $\%^{\mathrm{e}}$ & C.L. & $\operatorname{Mean}^{\mathrm{f}}$ & $\% \mathrm{~g}$ \\
\hline \multirow[t]{6}{*}{ NE } & EAFB Fish Hatchery ${ }^{i}$ & 2.40 & 42 & 36 & 8 & 22.00 & $(0.09-0.36)$ & 0.00 & 39 \\
\hline & Eagle Glen Golf Course ${ }^{\mathrm{i}}$ & 2.40 & 48 & 48 & 31 & 65.00 & $(0.51-0.79)$ & 2.00 & \\
\hline & Otter Lake & 5.70 & 60 & 34 & 19 & 56.00 & $(0.39-0.73)$ & 2.00 & \\
\hline & Cheney Lake & 6.30 & 293 & 101 & 15 & 15.00 & $(0.00-0.14)$ & 8.00 & \\
\hline & Windsong Park & 7.00 & 63 & 32 & 2 & 6.00 & $(0.08-0.22)$ & 0.00 & \\
\hline & University Lake & 8.10 & 188 & 66 & 5 & 8.00 & $(0.02-0.14)$ & 2.00 & \\
\hline \multirow[t]{4}{*}{ NW } & Westchester Lagoon & 8.40 & 388 & 155 & 18 & 12.00 & $(0.07-0.17)$ & 2.50 & 36 \\
\hline & Westchester Lake & 8.40 & 343 & 160 & 33 & 21.00 & $(0.15-0.27)$ & 2.50 & \\
\hline & Aleut Plaza & 8.80 & 146 & 44 & 10 & 23.00 & $(0.11-0.35)$ & 2.30 & \\
\hline & AIA/Lakes Hood and Spenard ${ }^{\mathrm{i}}$ & 12.10 & 222 & 62 & 14 & 23.00 & $(0.13-0.34)$ & 0.00 & \\
\hline \multirow[t]{6}{*}{ SW } & Taku Park & 11.20 & 64 & 32 & 0 & 0.00 & h & 0.00 & \\
\hline & Delong Lake & 13.40 & 15 & 8 & 0 & 0.00 & $-{ }^{\mathrm{h}}$ & 0.00 & 16 \\
\hline & Sand Lake & 14.70 & 185 & 66 & 1 & 2.00 & $(0.00-0.05)$ & 0.00 & \\
\hline & C St. \& O’Malley Borrow Pits & 15.60 & 117 & 50 & 7 & 14.00 & $(0.04-0.24)$ & 3.00 & \\
\hline & Jewel Lake & 15.60 & 90 & 41 & 0 & 0.00 & $-\mathbf{h}$ & 0.00 & \\
\hline & Campbell Lake & 15.60 & 443 & 158 & 12 & 8.00 & $(0.04-0.12)$ & 2.00 & \\
\hline \multirow[t]{4}{*}{ SE } & Reflection Lake & 8.10 & 157 & 51 & 21 & 41.00 & $(0.28-0.55)$ & 4.30 & 9 \\
\hline & Waldron Pond & 8.90 & 119 & 42 & 9 & 21.00 & $(0.09-0.33)$ & 2.50 & \\
\hline & Anchorage Golf Course & 14.00 & 107 & 42 & 3 & 7.00 & $(0.00-0.15)$ & 6.00 & \\
\hline & Huffman/Seward & 14.90 & 23 & 8 & 0 & 0.00 & $-{ }^{\mathrm{h}}$ & 0.00 & \\
\hline
\end{tabular}

\footnotetext{
${ }^{a}$ Distance $(\mathrm{km})$ capture site from EAFB runways.

${ }^{b}$ Number of geese available for marking at capture sites.

${ }^{\mathrm{c}}$ Number of geese collared at capture sites.

${ }^{\mathrm{d}}$ Number of collared geese observed of EAFB.

${ }^{\mathrm{e}}$ Percentage observed on EAFB by capture site.

${ }^{\mathrm{f}}$ Mean number of multiple visits onto.EAFB by collared geese by capture site.

${ }^{\mathrm{g}}$ Percentage observed on EAFB by quadrant.

${ }^{\mathrm{h}}$ No validity in sampled population.

${ }^{i}$ Geeise translocated to Palmer Hay Flats $(32 \mathrm{~km})$.
} 
Using these observations we identified three staging areas frequently used prior to entering EAFB $(\bar{x}=6.8, \mathrm{SE}=2.3 \mathrm{~km}$ from $\mathrm{EAFB})$, and two dispersal sites to which geese dispersed post-hazing $(\bar{x}=2.9, \mathrm{SE}=0.2 \mathrm{~km})$ (Fig. 1). These data were not available for neckbanded geese observed on AIA or MFA.

We observed 75 neckbanded geese on AIA from seven molting sites $(\bar{x}=5.73, \mathrm{SE}=3.35 \mathrm{~km}$ from AIA). Of those 75 geese observed at AIA $23 \%$ returned more than once after being hazed from AIA ( $\bar{x}$ reobservation rate $=2.90, \mathrm{SE}=0.50$ visits $)$. We observed 141 neckbanded geese on MFA from 14 molting sites $(\bar{x}=5.32, \quad \mathrm{SE}=2.57 \mathrm{~km}$ from MFA). Of those, $21 \%$ returned more than once after being hazed from MFA $(\bar{x}=2.53, \mathrm{SE}=0.92$ visits). The time between post-hazing return visits varied for geese on AIA $(\bar{x}=9.97, \mathrm{SE}=14.40$ days, range $=0.05-66$ days $)$ and MFA $(\bar{x}=15.0$, $\mathrm{SE}=20.70$ days, range $=1-55$ days).

We calculated median and maximum distances for movements of neckbanded geese throughout Anchorage over the course of the study (Fig. 2). Observations of all neckbanded geese from August through October indicated usage of a wide range of feeding and loafing sites $(\bar{x}=51.70, \mathrm{SE}=23.10$ sites) throughout Anchorage. Feeding and loafing sites used by all neckbanded geese (grouped by 10-one week periods) peaked during the period, 21-27 September $(\bar{x}=19.50, \quad \mathrm{SE}=2.80$ sites) (Fig. 3).

\section{Discussion}

The number of geese we observed on EAFB constitute a threat to aircraft safety. The majority of neckbanded geese originated from molting sites within an approximate radius of $9 \mathrm{~km}$, suggesting geese molting closer to EAFB are more likely to move into operational airspace. We recommend a substantial reduction in goose numbers at molting sites within this 9 $\mathrm{km}$ radius to improve aircraft safety at EAFB. As suggested by Cooper (1991) bird aircraft strike hazards can be dramatically reduced by identifying the local origins of breeding geese using an airport and removing them. Staging and dispersal sites identified by this study could also provide opportunities to control geese that have repeatedly entered airports.

Of special concern to aircraft safety are geese which returned to airports multiple times following hazing (approximately $20 \%$ of visiting geese). These geese substantially impact aircraft safety because they may have become habituated to non-lethal scare tactics. Schultz et al. (1988) found that some geese returned to feeding locations even after they were hunted. The returning geese we observed may be the result of habit-

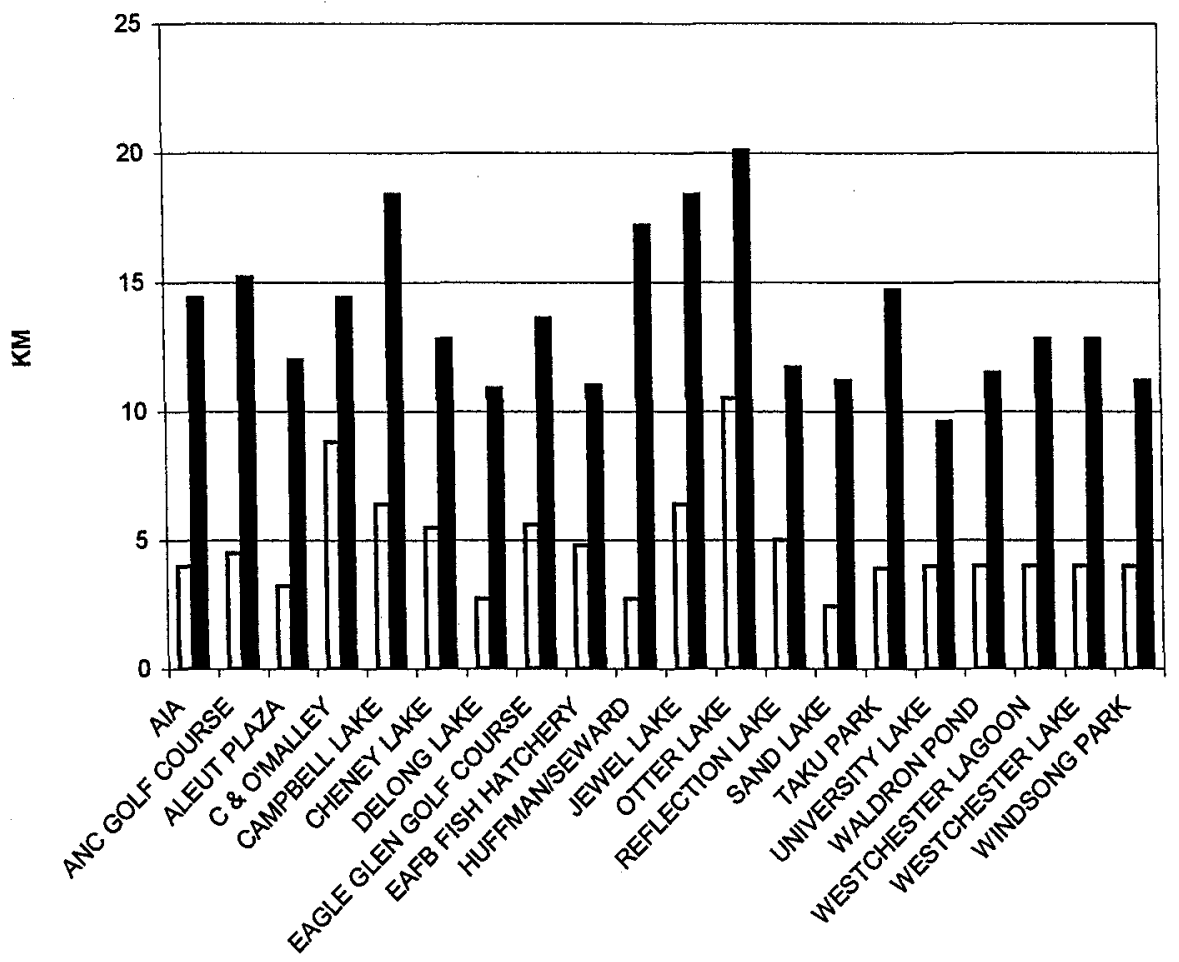

DMEDIAN DISTANCE MOVED (km) IMAXIMUM DISTANCE MOVED (km)

Fig. 2. Neckbanded Canada goose movements grouped by molting sites $(n=20), 13$ August through 14 October 1997. 
ual site use and not habituation to scare tactics, but either way these returning geese present a real threat to aircraft safety and require the increased use of lethal control on recognized individuals at Anchorage airports.

Cooper (1991) found at the Minneapolis, St. Paul International Airport that certain goose groups from the surrounding area consistently moved onto the airport more than others and by removing these geese the bird/aircraft strike hazard was reduced. We concluded that numerous geese move onto EAFB in late September and early October along with an increased utilization of feeding sites during autumn. Similarly, $40 \%$ of wildlife strikes to civil aircraft in the United States occurred from August through October for the 7-year period between 1991 and 1997 (Cleary et al., 1998). This dictates a need for increased surveillance and control efforts at airports during this season of premigratory staging when geese are especially active and abundant in Anchorage.

We have determined that the geese we translocated only provided short-term relief in reducing risks to aircraft safety because $26 \%$ of neckbanded geese observed on EAFB had been previously translocated. Translocating geese to the north placed EAFB between them and Anchorage molting and breeding sites, where they originated, perhaps explaining the large number of translocated geese we observed on EAFB when they regained flight. Any management action which might encourage goose flight paths over an airport must be avoided to lessen the possibility of geese entering active airspace as they attempt to return to original capture locations. Translocation efforts in the Metropolitan Twin Cities Area suggested translocation can be beneficial in reducing goose numbers by $50 \%$ over a period of five or more years (Cooper and Keefe, 1997).

Other goose control methods to be explored include egg oiling, hunter harvest, chemical repellents, and direct removal. Treatment of goose eggs with a single application of white mineral oil in the Seattle area proved effective, inexpensive, environmentally and socially acceptable as a management tool preventing local population increase if nests were clustered (Cummings et al., 1991). The chemical repellents, methyl anthranilate (AG-36) and DRC-156 could prove useful in deterring geese foraging on treated sites near airport runways if applied in combination with a diverse management plan, but the need for repeated applications and the associated costs restrict the feasibility of this method on a large-scale control effort (Conover, 1985; Cummings et al., 1991). In addition, Dolbeer et al. (1998) concluded that Flight Control ${ }^{(i)}$ (active ingredient: $50 \%$ anthraquinone), now registered with the U.S. Environmental Protection Agency (Reg. No. 69969-1) as a general use turf treatment against geese, was effective as a grazing repellent for Canada geese in pen experiments.

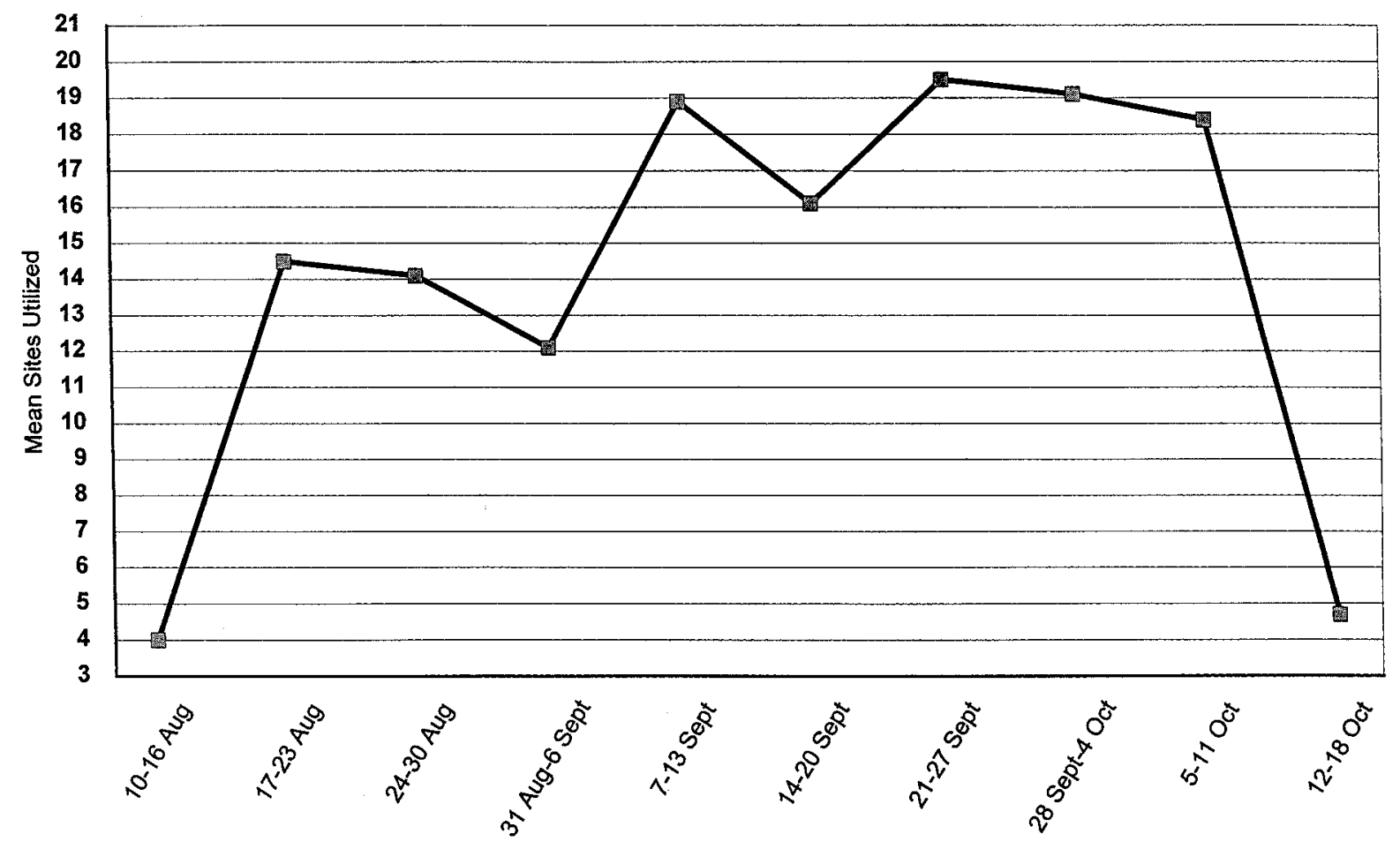

Fig. 3. Mean number of feeding/loafing sites utilized by all neckbanded Canada geese during the 10-one week survey periods. 
Cooper and Keefe (1997) concluded that hunting was the least costly goose population management technique and was effective in reducing goose density in hunted areas, and was especially effective when combined with removals (e.g., trapping and processing, and translocation) in reducing overall numbers in the Twin Cities Area. Hunting in acceptable areas, in and around Anchorage, would be beneficial in reducing overall goose numbers and consequently help reduce the incidence of geese moving onto Anchorage airports. If winter populations can be identified, liberalized harvest regimes in these areas could be used to help control nuisance flocks (Conover and Chasko, 1985). However, dusky Canada geese (B. c. occidentalis) and lesser Canada geese from Anchorage, winter in the same areas of western Oregon and southwestern Washington. As such, concerns over the declining dusky population and difficulty in distinguishing these from other subspecies of Canada geese limit harvest opportunities for lessers on their winter range (Hills and Naughton, 1991).

We recommend an integrated management approach utilizing various control techniques and direct manipulation of habitat which is acceptable to Anchorage residents. The proposed action (Alternative $\mathrm{C}$ ) in the Environmental Assessment (USFWS, 1998) to control the Anchorage Canada goose population provides for a population of 2000 geese, approximately half the current goose population. This alternative calls for the direct removal of approximately 730 adult geese and reducing production by 290 juveniles through egg collection and translocation of juveniles from 1998 through 2001. In order to maintain this target level of 2000 geese approximately 150 adults would be removed annually combined with egg collections and juvenile translocations equaling a reduction of approximately 100 juveniles on an annual basis (USFWS, 1998). Local airport managers believe safety hazard to aircraft will still be significant with 2000 geese in Anchorage, since potential strike hazards would be reduced by only half of the 1996 level. Costs of dispersing geese should also be reduced, as well as noise complaints from adjacent home owners resulting from hazing programs (USFWS, 1998).

Burger (1983) suggested that no single technique is $100 \%$ effective in reducing bird use of airports, so it is essential that many techniques be considered and utilized. Although we identified various sites from where geese originated prior to movement onto area airports, selecting certain sites for control efforts and ignoring the substantial growth in the city-wide population would provide only temporary relief and no guarantee of increased aircraft safety. As long as the Anchorage goose population is allowed to increase, large numbers of geese will arrive from anywhere in
Anchorage and enter area airports creating a variety of management problems and a serious risk to aircraft safety.

\section{Acknowledgements}

A special thanks to D. Crowley, ADFG, for providing his expertise in the goose trapping/collaring effort. We thank NWRC personnel J. Bourassa for mapping, J. Davis, N.P. Groninger, P. Pochop, and WS personnel C. Rossi, T. Smith and J. Spiegel for assistance in the capture and observation of geese. Thanks to A. Richmond, EAFB, for advice and technical assistance. We also thank R. Sinnot, ADFG, and K. Laing, USFWS for their assistance in various aspects of the study.

\section{References}

Arrington, D.P., 1994. U.S. air force bird aircraft strike hazard (BASH) summary report for 1989-1993. Bird Strike Committee - Europe 22, 201-208.

Bird, J., 1996. Birds: crash puts new focus on old problem. Air Force Times 26, 10-15.

Blokpoel, H., 1976. Bird Hazards to Aircraft: Problems and Prevention of Bird/Aircraft Collisions. Clark Irwin, Ottawa, Ont, p. 236.

Burger, J., 1983. Bird control at airports. Environmental Conservation 10, 115-124.

Cleary, E.C., Wright, S.E., Dolbeer, R.A., 1997. Wildlife strikes to civil aircraft in the United States 1992-1996. DOT/FAA/AAS/973. Fed. Aviation Admin., Office of Airport Safety and Standards, Washington, DC, pp. 30.

Cleary, E.C. Wright, S.E. Dolbar, R.A., 1998. Wildlife strikes to civil aircraft in the United States 1991-1997. DOT/FAA/AAS/984. Fed. Aviation Admin., Office of Airport Safety and Standards, Washington, DC, $34 \mathrm{pp}$.

Conover, M.R., 1985. Alleviating nuisance goose problems through methiocarb-induced aversive conditioning. Journal of Wildlife Management 49, 631-636.

Conover, M.R., Chasko, G.G., 1985. Nuisance Canada goose problems in the eastern United States. Wildlife Society Bulletin 13, 228-233.

Cooper, J.A., 1991. Canada goose management at the Minneapolis, St. Paul International Airport. In: Adams, L.W., Leedy, D.L. (Eds.), Wildlife Conservation in Metropolitan Environments. Proceedings of the National Symposium on Urban Wildlife, National Institute for Urban Wildlife, Columbia, MD, pp. 175183.

Cooper, J.A., Keefe, T., 1997. Urban Canada goose management: policies and procedures. Transactions of the North American Wildlife and Natural Resource Conference 62, 412-430.

Crowley, D.W., 1998. Status of the urban population of Canada geese in Anchorange, Alaska - 1998. Unpublished report. Division of Wildlife Conservation, Alaska Department of Fish and Game, Anchorange. Alaska Department of Fish and Game, 333 Raspberry Road, Anchorange, AK 99518, 11 pp.

Cummings, J.L., Otis, D.L., Davis Jr., J.E., Crane, K.A., 1991. Potential repellents for reducing Canada goose depredations. In: Proceedings of the Interenational Canada Goose Symposium, Milwaukee, WI, pp. 104-105. 
Dolbeer, R.A., Seamans, T.W., Blackwell, B.B, Belant, J.L., 1998 Anthraquinone formulation (Flight Control ${ }^{(* i w)}$ shows promise as avian feeding repellent. Journal of Wildlife Management 62 , 1558-1564.

Forbes, J.E., 1996. Bird Strikes. Reducing the chance of disaster. Airports North America, 14-15.

Hills, M.R., Naughton, M.B., 1991. Factors affecting the management of dusky Canada geese in western Oregon and southwestern Washington. In: Proceedings of the International Canada Goose Symposium, Milwaukee, WI, 166-168.

Kalbfleish, J.D., Prentice, R.L., 1980. The Statistical Analysis of Failure Time Data. Wiley, New York.

Kaplan, E.L., Meier, P., 1958. Nonparametric estimation from incomplete observations. Journal of the American Statistical Association 53, 457-481.
Miller, R.D., Dobrovolny, E., 1959. Surficial geology of Anchorage and vicinity, Alaska. USGS Bulletin No. 1093.

Rothe, T.C., 1994. Canada geese. Alaska Department of Fish and Game - Wildlife Notebook Series 2.

Schultz, D.F., Cooper, J.A., Zicus, M.C., 1988. Fall flock behavior and harvest of Canada geese. Journal of Wildlife Management $52,679-688$.

U.S. Fish and Wildlife Service, 1993. Anchorage wetlands trends study (1950-1990). USDI Fish and Wildlife Service. Available from: U.S. Fish and Wildlife Service, 1011 E. Tudor Road, Anchorage, Alaska 99503.

U.S. Fish and Wildlife Service, 1998. Canada goose population management in Anchorage, Alaska. Environmental Assessment prepared in consultation with the Anchorage Waterfowl Working Group, $47 \mathrm{pp}$. and appendices. 